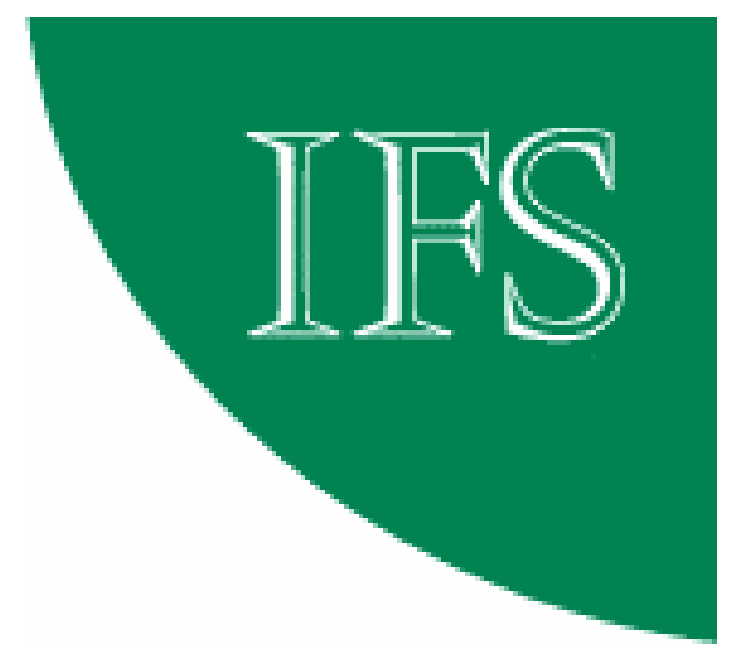

\title{
PRODUCT MARKET REFORMS, LABOUR MARKET INSTITUTIONS AND UNEMPLOYMENT
}

\author{
Rachel Griffith \\ Rupert Harrison \\ Gareth Macartney
}




\title{
Product Market Reforms, Labour Market Institutions and Unemployment
}

\author{
Rachel Griffith, Rupert Harrison and Gareth Macartney \\ Institute for Fiscal Studies, University College London and AIM
}

February 2006

\begin{abstract}
We analyze the impact of product market competition on unemployment and wages, and how this depends on labour market institutions. We use differential changes in regulations across OECD countries over the 1980s and 1990s to identify the effects of competition. We find that increased product market competition reduces unemployment, and that it does so more in countries with labour market institutions that increase worker bargaining power. The theoretical intuition is that both firms with market power and unions with bargaining power are constrained in their behaviour by the elasticity of demand in the product market. We also find that the effect of increased competition on real wages is beneficial to workers, but less so when they have high bargaining power. Intuitively, real wages increase through a drop in the general price level, but workers with bargaining power lose out somewhat from a reduction in the rents that they had previously captured.
\end{abstract}

JEL codes: E24, J50, L50.

Keywords: product market regulation; competition; wage bargaining; unemployment.

Acknowledgements: The authors would like to thank Sami Berlinski, Richard Blundell, Wendy Carlin, Steve Nickell, Nicola Pavoni, Reinhilde Veugelers, and Fabienne Ilkovitz and other seminar participants at the European Commission for helpful comments. This work was funded by the ESRC/EPSRC funded Advanced Institute for Management Research (AIM) and the ESRC Centre at IFS.

Correspondence: rgriffith@ifs.org.uk, rharrison@ifs.org.uk, gareth_m@ifs.org.uk; IFS, 7 Ridgmount Street, London WC1E 7AE, UK. 


\section{Executive Summary}

High rates of unemployment remain a key policy concern across many European countries. There is a large literature investigating the role of unions, taxes, and other labour market institutions in explaining variation in unemployment rates across countries. In a recent contribution to this literature, Nickell et al (2005) find that changes in these factors can explain about 55\% of the rise in European unemployment from the 1960s to the first half of the 1990s. However, it seems likely that changes in labour market institutions alone cannot explain the wide divergences in unemployment experiences across countries. For example, Blanchard (2005) argues that a complex interaction between institutions and other shocks provides an important part of the explanation.

In particular, conditions in the product market are also likely to play an important role. Theory suggests that product market competition is a key determinant of employment - in imperfectly competitive markets firms restrict output and thus employment. More intense competition pulls prices closer to marginal cost, increasing output demanded by consumers and, therefore, labour demanded by producers. A number of recent theoretical papers have emphasized the role of product market competition, as well as potentially important interactions between competition and labour market institutions. A recognition of the role of competition also lies behind many of the current attempts to reform product markets in Europe, including those laid out in the Lisbon Agenda and the Services Directive.

In this paper we investigate the impact of increased product market competition on employment and wages using data across OECD countries over the 1980s and 1990s. Our contribution to the literature is twofold. First, we use time-varying policy reforms to provide exogenous variation in product market conditions, enabling us to provide stronger evidence that competition increases employment and real wages than exists so far. We show that these effects have been quantitatively important in explaining movements in unemployment and wages in OECD countries over the past twenty years.

Secondly, we provide evidence that the size of these effects varies with labour market institutions. Theory suggests that the positive impact of competition on employment is greater where workers' bargaining power is high. The reason for this is that unions who care about employment as well as wages are constrained by the level of competition in the product market. 
Therefore an increase in competition in an economy with both monopolistic firms and unions will lead to greater reductions in prices and greater increases in output than in an economy without unions. In contrast, under some conditions the positive impact of competition on real wages may be smaller when workers have more bargaining power, since the negative impact of competition on the general price level may be partially offset by a reduction in the level of rents captured by workers.

We use the substantial market liberalisations that have occurred across countries over the past two decades to provide exogenous variation in competitive conditions. These include reforms that reduce barriers to entry, tariff rates and regulatory barriers to trade, remove price controls and reduce public involvement in production. We find strong evidence that reforms such as these decrease the average level of profits in the economy, which in turn increases employment and real wages. The positive effect on employment is found to be greater, and the positive effect on real wages lower, in economies with greater worker bargaining power (those with higher collective bargaining coverage and/or higher union membership). To capture cross-country variation in bargaining power we use initial values of bargaining coverage and unionisation in order to mitigate possible endogeneity problems.

In the literature there is strong empirical evidence that labour market institutions matter in determining labour market outcomes, there are strong theoretical reasons to believe that product market regulations are also important, but there is little empirical evidence to support this. In addition, some theory suggests that the impact of product market competition on labour market outcomes varies with labour market institutions. There is, however, even less empirical evidence to support this latter prediction.

Our results have interesting implications for policy. First, widespread product market reforms will benefit workers and the economy as a whole through increased employment and higher real wages. Second, the presence of strong unions is not a reason to shy away from product market reform - if anything there is more incentive to reform as the employment benefits may be larger. However, it is also under these circumstances that reform may be most resisted as existing workers have less to gain. 


\section{Introduction}

High rates of unemployment remain a key policy concern across many European countries. Following the OECD Jobs Study (1994) a large literature has investigated the role of unions, taxes, and other labour market institutions in explaining variation in unemployment rates across countries. ${ }^{1}$ In a recent contribution to this literature, Nickell et al (2005) find that changes in these factors can explain about 55\% of the rise in European unemployment from the 1960s to the first half of the 1990s. However, it seems likely that changes in labour market institutions alone cannot explain the wide divergences in unemployment experiences across countries. For example, Blanchard (2005) argues that a complex interaction between institutions and other shocks provides an important part of the explanation.

In particular, conditions in the product market are also likely to play an important role. Theory suggests that product market competition is a key determinant of employment - in imperfectly competitive markets firms restrict output and thus employment. More intense competition pulls prices closer to marginal cost, increasing output demanded by consumers and, therefore, labour demanded by producers. A number of recent theoretical papers have emphasized the role of product market competition, as well as potentially important interactions between competition and labour market institutions. ${ }^{2}$ A recognition of the role of competition also lies behind many of the current attempts to reform product markets in Europe, including those laid out in the Lisbon Agenda and the Services Directive.

In this paper we investigate the impact of increased product market competition on employment and wages using data across OECD countries over the 1980s and 1990s. Our contribution to the literature is twofold. First, we use time-varying policy reforms to provide exogenous variation in product market conditions, enabling us to provide stronger evidence that competition increases employment and real wages than exists so far. We show that these effects have been quantitatively important in explaining movements in unemployment and wages in OECD countries over the past twenty years.

\footnotetext{
${ }^{1}$ See, amongst others, Elmeskov, Martin and Scarpetta (1998), Nickell and Layard (1999), Blanchard and Wolfers (2000), Belot and van Ours (2001).

${ }^{2}$ See for example Blanchard and Giavazzi (2003), Spector (2004) and Ebell and Haefke (2004).
} 
Secondly, we provide evidence that the size of these effects varies with labour market institutions. Theory suggests that the positive impact of competition on employment is greater where workers' bargaining power is high. The reason for this is that unions who care about employment as well as wages are constrained by the level of competition in the product market. Therefore an increase in competition in an economy with both monopolistic firms and unions will lead to greater reductions in prices and greater increases in output than in an economy without unions. In contrast, under some conditions the positive impact of competition on real wages may be smaller when workers have more bargaining power, since the negative impact of competition on the general price level may be partially offset by a reduction in the level of rents captured by workers.

We use the substantial market liberalisations that have occurred across countries over the past two decades to provide exogenous variation in competitive conditions. These include reforms that reduce barriers to entry, tariff rates and regulatory barriers to trade, remove price controls and reduce public involvement in production. We find strong evidence that reforms such as these decrease the average level of profits in the economy, which in turn increases employment and real wages. The positive effect on employment is found to be greater, and the positive effect on real wages lower, in economies with greater worker bargaining power (those with higher collective bargaining coverage and/or higher union membership). To capture cross-country variation in bargaining power we use initial values of bargaining coverage and unionisation in order to mitigate possible endogeneity problems.

Our work is related to three key literatures. First, as discussed above, there is a substantial empirical literature investigating the labour market determinants of unemployment. In general this work finds that labour market institutions, taxes and benefits have important effects on the level of employment, although the nature and size of the effects varies somewhat across studies.

Secondly, there is a body of theoretical work on the impact of product market regulations on employment and wages. Static equilibrium models of monopolistic competition in the goods market and bargaining over employment and wages in the labour market suggest that increasing 
product market competition increases employment and real wages. ${ }^{3}$ Dynamic models of firms' labour demand in the presence of wage bargaining confirm these results. ${ }^{4}$ These models also suggest that the employment increase is greater when workers bargain collectively, even when the workers' choice of bargaining regime is endogenised as in Ebell and Haefke (2004).

Thirdly, there is a recent and smaller empirical literature on the impact of product market regulations on employment and wages. At the micro level, Bertrand and Kramarz (2002) look at the impact of entry restrictions introduced in the French retail industry to protect small businesses from large suppliers. They find that such restrictions reduced employment but did not have a significant effect on wages, possibly because most employees in this sector are paid the minimum wage. Kugler and Pica (2003) use micro data from Italy and find that strict product market regulations reduce the effects of labour market reforms on employment. Andersen, Haldrup and Sorensen (2000) find evidence that increased trade in the EU, possibly due to increased liberalisation through schemes such as the Single Market Programme, lead to increased wage convergence and an increase in cross border wage dependency. Pissarides (2001) finds a negative correlation between a measure of business start-up costs and employment rates across a sample of OECD countries.

Most similar to this paper, Nicoletti and Scarpetta (2005) estimate the impact of product market reforms on employment rates across OECD countries, as well as a range of potential interactions between product market reforms and labour market institutions. Consistent with the discussion above, they find that restrictive product market regulations have reduced employment rates in some OECD countries, particularly those where labour market institutions provide strong bargaining power to insiders. Our approach differs from Nicoletti and Scarpetta (2005) in a number of important ways. First, we use indicators of product market reforms that affect both traded and non-traded sectors of the economy, rather than a selection of seven regulated 'network' industries as in their case. Regulation in the industries they consider has very different characteristics to the barriers to entry and competition in the rest of the economy, and trends in

\footnotetext{
${ }^{3}$ Nickell (1999) discusses some of the main intuitions. The basic framework of several recent papers draws on elements of Dixit and Stiglitz (1977) and Blanchard and Kiyotaki (1987). Blanchard and Giavazzi (2003) is a model without capital. Spector (2004) introduces capital and finds the same result for employment, but finds that real wages may actually decrease following an increase in competition.
}

${ }^{4}$ Ebell and Haefke (2004), Commendatore and Kubin (2005). 
these industries are unlikely to be representative of overall trends in product market regulation. Secondly, we allow the impact of product market reforms to vary across different types of reform, rather than imposing strong a priori restrictions by calculating a single index of regulation. ${ }^{5}$ Thirdly we investigate the parallel predictions of theory for real wages as well as employment. And finally, drawing on the underlying theoretical motivation, we explicitly model the impact of product market reforms on competition, as proxied by the average level of profits in the economy. Without this step the channel for the impact of product market regulations on employment and wages is not clear.

In summary, there is strong empirical evidence that labour market institutions matter in determining labour market outcomes, there are strong theoretical reasons to believe that product market regulations are also important, but there is little empirical evidence to support this. In addition, some theory suggests that the impact of product market competition on labour market outcomes varies with labour market institutions. There is, however, even less empirical evidence to support this latter prediction.

The structure of the paper is as follows. Section 2 sets out a theoretical framework. In section 3 we explain our empirical methodology and discuss the data. Section 4 presents the results, and a final section concludes.

\footnotetext{
${ }^{5}$ Previous work has suggested that this is an important consideration. See Griffith and Harrison (2004).
} 


\section{Theoretical framework}

Product market competition provides a constraint on both the price-setting behaviour of firms and the wage-setting behaviour of unions. In a simple model firms set prices as a mark-up over wages, and the mark-up is determined by the elasticity of demand for their product. Increasing competition reduces the mark-up firms can apply, leading to increased output and hence employment. Unions bargain with firms to set a wage, in the knowledge that firms will take a mark-up over this wage. As such, unions know that high wages will be passed to consumers as higher prices and will result in lower output, more so when the elasticity of demand is higher. Therefore, when unions care about employment as well as wages, increasing competition will lead them to further limit their wage bargaining. Hence, increasing competition in the product market will increase employment, and by more so when union bargaining power is high.

In this section we briefly illustrate this effect in a standard closed economy model of monopolistic competition in goods, in the presence of firm level union bargaining. The model is based closely on Chapter 15 of Carlin and Soskice (2005), and consists of elements from the classic models of Dixit and Stiglitz (1977) and Blanchard and Kiyotaki (1987). Very similar results arise in the model of Jackman, Layard and Nickell (1991) and in more recent work by Blanchard and Giavazzi (2003) and Spector (2004) amongst others. We also discuss the effect of competition on the real wage, and briefly consider the impact of coordinated bargaining at an industry or economy-wide level.

\subsection{Monopoly firms, monopoly unions}

Consider a closed economy with $\mathrm{N}$ sectors, each consisting of one firm and one consumerworker, and each represented by one union. Firms use labour to produce a single good, and the goods are imperfect substitutes. Worker-consumers have constant elasticity of substitution preferences and an increasing aversion to work. ${ }^{6}$ Firms monopolise their sectors and unions monopolise firms, as they control all of the labour in their sector.

\footnotetext{
${ }^{6}$ The increasing marginal disutility of work is necessary for a unique equilibrium in the presence of constant returns to scale production. It captures the idea that workers have a higher reservation wage in times of high employment, due for example to increased personal wealth, household income or more opportunities for employment.
} 
The output of firm $i$ is $y_{i}=e_{i}$, where $y$ denotes output and $e$ denotes employment. Demand for a firm's product is determined by its relative price, which is given by $y_{i}=p_{i}^{-\eta} A / N$, where $p$ is the nominal price, $\eta$ is the elasticity of demand, A indicates the level of aggregate demand in the economy and $\mathrm{N}$ is the number of sectors. Firms choose the relative price to maximise profits for a given wage, constrained by the elasticity of demand in their product market. That is, they solve the following:

$$
\max _{p_{i}} \Pi_{i}=p_{i} y_{i}-w_{i} e_{i}, \quad \text { subject to } y_{i}=p_{i}^{-\eta} A / N
$$

where $\Pi$ are profits and $w$ is the cost of a unit of labour. The resulting first order condition gives us the price-setting schedule:

$$
p_{i}=\frac{\eta}{\eta-1} w_{i}
$$

As competition increases, the relative price tends to the cost of labour, i.e. as $\eta \rightarrow \infty, p_{i} \rightarrow w_{i}$. Each monopoly union can set the real wage that maximises its utility, subject to the firm's pricesetting behaviour, and constrained by the elasticity of demand in the product market. The union's utility is that of the representative worker, consisting of the workers income minus the disutility of work. Therefore, the union solves: ${ }^{7}$

$$
\max _{w_{i}} U_{i}=w_{i} e_{i}-\frac{\phi e_{i}{ }^{\sigma}}{\sigma}, \quad \text { subject to } p_{i}=\frac{\eta}{\eta-1} w_{i}, \text { and } y_{i}=e_{i}=p_{i}^{-\eta} A / N
$$

where $U$ is the union's utility function, $\sigma$ is the employment elasticity of the disutility of employment (and is greater than one if the marginal disutility of employment is increasing), and $\phi$ is a scaling parameter. The resulting first order condition gives us the wage-setting schedule:

$$
w_{i}=\frac{\eta \phi}{\eta-1} e_{i}^{\sigma-1}
$$

\footnotetext{
${ }^{7}$ In this model the representative worker's effort is bounded between zero and one, and can be thought of as an employment rate. An increasing marginal disutility of effort means that $\sigma>1$.
} 
As competition increases, the real wage tends to the marginal disutility of effort, i.e. as $\eta \rightarrow \infty, w_{i} \rightarrow \phi e_{i}^{\sigma-1}$

Taking logs of (1) and (2) and aggregating by averaging over all sectors, ${ }^{8}$ we obtain:

$$
\log p=\log \frac{\eta}{\eta-1}+\log w^{P S}
$$

$$
\log w^{W S}=\log \frac{\eta \phi}{\eta-1}+(\sigma-1) \log e
$$

By symmetry, the prices in all sectors are the same and therefore $\log p=0$. An equilibrium is an employment level where the real wage is acceptable to both wage setters and price setters, i.e. $\log w^{W S}=\log w^{P S}$ ?

We can express competition in terms of the mark-up, $\mu=\frac{1}{\eta-1}$, and therefore $1+\mu=\frac{\eta}{\eta-1}$.

Solving the above equations and using this expression for the mark-up yields:

$$
\log e_{e}^{\text {DoubleMonopoly }}=\frac{1}{\sigma-1} \log \left[\phi^{-1}\left(\frac{1}{1+\mu}\right)^{2}\right]
$$

We can compare this, first, to a situation with imperfect product market competition but no unions (equation 6), and, second, to the perfectly competitive outcome (equation 7):

$$
\begin{aligned}
& \log e_{e}^{\text {FirmMonopoly }}=\frac{1}{\sigma-1} \log \left[\phi^{-1}\left(\frac{1}{1+\mu}\right)\right], \\
& \log e_{e}^{\text {Competitive }}=\frac{1}{\sigma-1} \log \left[\phi^{-1}\right] .
\end{aligned}
$$

${ }^{8}$ Using $\log \mathrm{x}=\mathrm{N}^{-1} \Sigma \log \mathrm{x}$

9 This is the non-accelerating inflation employment rate. An inflation-targeting central bank will adjust the interest rate to maintain this equilibrium. 
As we would expect $\log e_{e}^{\text {Competive }}>\log e_{e}{ }^{\text {FirmMonopoly }}>\log e_{e}{ }^{\text {DoubleMonopoly }}$. One market imperfection leads to lower employment than none, and two to lower than with one. From expressions (5) and (6) it is also clear that an increase in product market competition that reduces the mark-up will increase employment, and will increase it more in the presence of a monopoly union. This is the key intuition that we attempt to investigate empirically.

In our empirical approach we use country level measures of collective bargaining coverage and trade union membership to capture variation in the nature of wage and employment setting. ${ }^{10}$ One way to interpret this is that countries with a higher proportion of workers covered by collective bargaining agreements or belonging to unions correspond more closely to the doublemonopoly case, while countries with lower levels of bargaining coverage or union membership correspond more closely to the single firm-monopoly case. For example, we could think of countries with higher levels of bargaining coverage or union membership as having a higher proportion of sectors characterized by the double-monopoly case.

An alternative interpretation is that collective bargaining coverage or union membership are summary measures of workers' bargaining power in a setting where there is bargaining between firms and unions. Union power may be constrained by a number of factors such as regulations on the right to strike, the extent of control over the workforce or the presence of other unions. At one extreme of workers' bargaining power lies the monopoly union and at the other extreme is the single firm monopoly, with a range of bargaining power in between. The intuition described above then has an equivalent as follows: an increase in product market competition that decreases the mark-up will increase employment more when workers' bargaining power is higher. ${ }^{11}$

${ }^{10}$ We also consider the role of bargaining coordination - see below for a discussion of this.

11 This result also comes directly out of recent theoretical models of product and labour market regulation. For example, in the case where firms have the right to manage it is implicit in equation (14) of Blanchard and Giavazzi (2003) and equation (6) of Spector (2004). The equivalent results for the case of efficient bargaining are equation (6) in Blanchard and Giavazzi (2003) and equation (7) in Spector (2004). In a dynamic framework, Ebell and Haefke (2004) find that the positive effect of competition on employment is greater when workers bargain collectively than when they bargain individually, even when the choice of bargaining institution is endogenous. 


\subsection{Wages}

In the model described above, the effect of increased competition on real wages is independent of union bargaining power. The real wage is entirely determined by product market conditions and it increases with competition; it follows from (3) that it is given by:

$$
\log w_{e}=\log \left[\frac{1}{1+\mu}\right]
$$

The result that the real wage is independent of union bargaining power is a direct consequence of the assumption that firms can set prices and employment conditional on the bargained wage. In this right to manage framework firms set prices as a mark-up over the bargained wage and the impact on the general price level offsets any increase in the bargained wage. If, on the other hand, we assume efficient bargaining, where firms and unions bargain over employment and the real wage simultaneously, then the real wage becomes a positive function of union bargaining power - workers are able to capture a proportion of the available rents that is increasing in their bargaining power. In this case an increase in competition that reduces the available rents will increase the real wage by a smaller amount when workers have higher levels of bargaining power. Competition hurts individuals as workers but, through its effect on the price level, benefits them as consumers.

As discussed in Blanchard and Giavazzi (2003), while efficient bargaining may not be a complete description of the actual bargaining processes, it does capture the possibility that, when there are rents, stronger workers may be able to obtain a higher wage without suffering a decrease in employment, at least in the short run. To the extent that this is the case, we would expect to see that the positive impact of competition on wages is smaller when workers have more bargaining power.

Another consideration with regard to wages concerns the role of fixed capital. In the presence of fixed capital in the production function, workers and firms will bargain over the resulting quasirents. Spector (2004) shows that in this case the overall impact of product market competition on wages may be negative, as the reduction in workers' rents and quasi-rents more than offsets the reduction in the price level. 


\subsection{A note on coordination}

Finally, an important characteristic of union bargaining is the degree to which unions coordinate their activities. Calmfors and Driffill (1988) argue that there should be a U-shaped relationship between employment and the degree of coordination. The reason for this is that unions have an incentive to coordinate in sectors that are close substitutes in order to decrease the elasticity of demand for their (combined) product. However, as the combined union becomes larger the effect of its wage demands on aggregate prices increases. Its members suffer from this and workerconsumers therefore moderate their demands, and employment increases. In this way an intermediate level of coordination, at the industry level for example, results in the lowest employment, since union bargaining power is high, but worker-consumers have little incentive to take into account the impact of their wage demands on the aggregate price level.

To the extent that true economy-wide coordination does lead to more moderate wage demands, we should expect to see that the interaction between product market competition and measures of union density or bargaining coverage is less strong in coordinated countries. However, to the extent that the main effect of coordination is to increase workers' bargaining power we should expect to find that the impact of competition on employment is larger (and the impact on wages smaller) in more coordinated economies. ${ }^{12}$ We test for these effects in the robustness section.

\subsection{Testable predictions}

From this discussion we take the following empirical predictions to the data:

1. Increased product market competition reduces unemployment.

2. The reduction in unemployment is larger when workers' bargaining power is higher.

3. Increased product market competition increases the real wage.

4. The increase in the real wage may be smaller when workers' bargaining power is higher, to the extent that bargaining deviates from the right to manage framework.

\footnotetext{
${ }^{12}$ For example, Flanagan (1999) argues that centralised bargaining in many OECD countries is "more form than substance" (p. 1167)
} 


\section{Empirical implementation and data}

The discussion above suggests that competition will affect the unemployment rate and real wages, and will do so differently in economies with different labour market institutions. We are therefore interested in empirically exploring the following relationships:

$$
\begin{aligned}
& U R_{i t}=\alpha_{1} \mu_{i t}+\alpha_{2} \mu_{i t}^{*} B P_{i}+\alpha_{3} L M R_{i t}+X_{i t}^{\prime} \alpha_{4}+f_{i}+t_{t}+\varepsilon_{i t}^{U} \\
& w_{i t}=\beta_{1} \mu_{i t}+\beta_{2} \mu_{i t} * B P_{i}+\beta_{3} L M R_{i t}+X_{i t}^{\prime} \beta_{4}+f_{i}+t_{t}+\varepsilon_{i t}^{W}
\end{aligned}
$$

where $i$ indexes countries and $t$ years, UR is the unemployment rate, $\mu$ is a measure of the average level of profits firms earn, $B P_{i 1}$ captures labour market regulations that indicate the bargaining power of workers in the economy (at the start of the sample period - see below), $L M R_{i t}$ is a vector of other labour market regulations and institutions, and $X_{i t}$ contains a set of cyclical and other controls, including a measure of the deviation of output from trend growth, the real exchange rate and the change in the inflation rate. $X_{i t}$ also contains the public sector employment rate to control for any potential impact of public sector employment in crowding out private sector employment. Of course public and private sector employment are likely to be jointly determined, so we check that our results are robust to dropping this variable from the set of controls. We do the same for the other controls, and also check that the results are robust to using employment rather than unemployment as the dependent variable. Country fixed effects are captured by country dummies, $f_{i}$, and common macro shocks by year dummies, $t_{t}$.

We capture the extent of product market competition by the average level of firm profitability in the economy, $\mu$. Therefore, a key issue in estimating (9) and (10) is the potential for measurement error and endogeneity of $\mu$. For example, a positive demand shock might increase both output and firm profitability. We pay careful attention to instrumenting $\mu$ using policy reforms to product markets. We show that the reforms we use affect average profitability in the economy in a sensible way and we confirm the power of our instruments. Our approach assumes that such reforms affect labour market outcomes only through their impact on competition and not directly, and we test the statistical validity of these exclusion restrictions. In order to identify the key parameters of interest separately from other cross country differences we need to have 
indicators of product market regulations and reforms that vary differentially over time across countries or industries.

In examining how the effect of competition depends on labour market institutions we focus on labour market characteristics that affect workers' bargaining power. We capture this using indicators of collective bargaining coverage and trade union membership, which in themselves may be endogenous: for example, an adverse shock on employment or wages may trigger an increase in union membership. Therefore, we use initial values of coverage and union density to capture variation in workers' bargaining power across countries. The implicit assumption is that bargaining power does not change significantly over time, and the data suggests that this is not an unreasonable assumption, particularly for bargaining coverage.

\subsection{Data}

In order to investigate these issues empirically we need data on (i) unemployment and wages, (ii) the extent of product market competition and indicators of exogenous product market reforms, (iii) labour market regulations, and (iv) other country characteristics. We discuss each of these in turn. The composition of the sample, sources and descriptive statistics are given in a data appendix.

\subsubsection{Unemployment and wages}

We use the OECD's standardised unemployment rate, which is the number of unemployed persons as a percentage of the civilian labour force. This is important because, in general, decreases in the unemployment rate are associated with increases in participation (e.g. see Blanchard (2005)). Our story is one of bargaining power and the medium run equilibrium in the labour market, so we are keen to isolate these from participation effects. However, we also check that our results are robust using employment rather than unemployment as a dependent variable.

We use two alternative measures of real wages. First we use a real wage index for manufacturing. Unfortunately, comparable wage data is not available for all countries in our sample at the total economy level. We therefore also use total economy labour costs, which includes payroll taxes, and control for the tax wedge and find similar results to manufacturing. 
Precise definitions, means and standard deviation of these variables are shown in Table A.2 in the data appendix.

\subsubsection{Product market competition and reforms}

We capture changes in the extent of competition using a measure of the average level of firm profitability. ${ }^{13}$ In a simple model of bargaining such as that set out in Section 2 this corresponds closely to the equilibrium mark-up over costs. We calculate the average level of profits as value added over costs:

$$
\mu_{i t}=\frac{\text { ValueAdded }_{i t}}{\text { LabourCosts }_{i t}+\text { CapitalCosts }_{i t}}
$$

where all variables are in nominal prices. ${ }^{14}$ We assume that all economies are open and use the US long term interest rate to proxy the time variation in the cost of capital. ${ }^{15}$ In our calculation of average profits, we exclude the public sector and agriculture and, where possible, we exclude the real estate sector which suffers from inflated values due to rising property prices. ${ }^{16}$ The average level of profitability in our sample is 1.31 and increases slightly over the period 1985 to 2000 . This measure is pro-cyclical and varies both within and between countries (see Table A.2 in the Data Appendix). ${ }^{17}$ We therefore include a measure of deviation from trend output growth and the change in the rate of inflation to control for country specific business cycles, as well as the real exchange rate to control for trade shocks. In addition, country dummies control for any differences in measurement that are constant over time.

\footnotetext{
${ }^{13}$ We can think of this as an estimate of the mark-up or price cost margin (similar to a Lerner Index) if average costs are close to marginal costs. This is shown by Boone (2001) to be theoretically preferable to most other commonly used measures of competition, especially those based on market concentration or the number of firms, and it most closely corresponds to the parameter specified in theoretical models.

${ }^{14}$ This can be shown to be equivalent to that proposed by Roeger (1995). See also Klette (1999) for a discussion.

15 We repeat the analysis using time-varying country specific interest rates (see the robustness section for some discussion).

${ }^{16}$ In Portugal we can not make these exclusions due to lack of data so we use the total economy. We can remove the real estate sector in Austria, Denmark, Finland, France, the Netherlands, Norway and the USA.

17 Overall, our measures are similar to other examples in the literature, for example those calculated for manufacturing industries by Martins, Scarpetta and Pilat (1996).
} 
At first the fact that average profitability trends upwards over time may seem to conflict with most preconceptions about changes to the degree of competition associated with product market reforms, globalisation and opening to trade. One explanation, discussed in Blanchard and Giavazzi (2003) and Boulhol (2004), is that upwards trending measured firm profits could be a short term response to reductions in the bargaining power of workers. The intuition is that declining bargaining power reduces the share of rents captured by workers in higher wages, and increases the share that are measured in firms' profits. ${ }^{18}$ In the long term, the increase in profitability associated with declining workers' bargaining power would be expected to lead to entry and a reduction of rents to their previous level, but to the extent that these effects occur with lags it is possible for the rent transfer effect to dominate the entry effect during the transition period. We control for these types of changes by including time-varying measures of labour market institutions in all specifications. In addition, any trends that are common across countries will be captured by year effects.

Finally, one drawback of our measure is that it contains the implicit assumption of constant returns to scale. This measure of profitability is biased downwards (upwards) in the presence of increasing (decreasing) returns to scale. However, since industrial structure does not change very quickly over time, any bias that might arise due to different levels of increasing returns to scale across countries should be captured by the fixed country effects in our econometric analysis. Similarly, any trends that are common across countries will be captured by year effects.

Key to our identification strategy is using time-varying indicators of product market reforms for each country. We use information on four types of reform - the implementation of the EU Single Market Programme (SMP), changes in tariff and non-tariff barriers and the burden of government bureaucracy.

The SMP was concerned with eradicating cross-country differences in product and service standards, administrative and regulatory barriers, VAT and capital controls which inhibited the free flow of goods, services and factors of production between EU countries. Of the 14 countries in our sample, seven were involved in the programme (Belgium, Denmark, France, the United

\footnotetext{
18 This is in a context of efficient bargaining. The intuition remains valid to the extent that bargaining deviates from the right-to-manage framework.
} 
Kingdom, Italy, the Netherlands and Portugal) and seven were not (Australia, Austria, Canada, Finland, Norway, Sweden, the USA). We also exploit the fact that, among participants, the SMP both had a differential effect across countries and was implemented at different rates.

To capture variation in the impact we use a survey carried out before the programme was implemented. Cecchini et al (1986) surveyed 11,000 firms in different industries asking respondents to rate the current level of various barriers to trade. Based on this survey Buiges et al (1990) identified 40 out of 120 industrial sectors that were deemed to be most sensitive to the programme. They consulted individual country experts to confirm their findings. We use the percentage of industry (specifically the percentage of employment) that was sensitive to the programme for each country. We also use the fact that different countries passed the reforms into law at different rates. The European Commission recorded this from 1997 onwards in its Internal Market Scoreboard and we modify our variable accordingly using differences across countries in the average rate of implementation. ${ }^{19}$ We combine these sources of variation to construct a variable that indicates the percentage of industry liberalized over time.

We also use three other indicators to supplement the variation provided by the Single Market Programme. The first is based on an indicator of the administrative burden on business from the World Economic Forum's Global Competitiveness Report, and is available for the 1990s. The indicator is provided by the Fraser Institute and is based on responses to the following question asked to 10,000 business leaders in the Executive Opinion Survey: "How much time does your firm's senior management spend dealing/negotiating with government officials?". A large amount of time spent with government bureaucracy may constitute a barrier to entry, hinder firms' expansion, or may indicate a significant amount of government involvement in business decision-making, all of which can inhibit competition.

The second is an index of average tariff rates. This is constructed by the Fraser Institute using data from a number of sources, including the World Bank, the OECD, UNCTAD and GATT. The third is a similar measure of the extent of non-tariff barriers to trade available for the 1990s. This is based on survey questions on hidden import barriers and the cost of importing equipment to measure changes in the trade environment that are not captured in the SMP variable. 
A description of the sources for these variables and their means and standard deviations are provided in Table A.3 in the data appendix.

In the results reported below we pay careful attention to showing that these reforms provide powerful instruments for the degree of profitability (in that they enter significantly in the first stage regression) and that they are valid instruments (in that they can be excluded from the second stage).

\subsubsection{Labour market regulations}

The labour market variables that we use fall into two categories: those that directly reflect worker bargaining power, which we use in the interaction with competition, and those that have been shown in the literature to affect unemployment, which we use as controls. The proportion of workers who are paid wages determined by firm/union bargaining whether or not they belong to a union (referred to as bargaining coverage), and the proportion of workers who are actual members of a union (referred to as union density) fall into the first category. We find bargaining coverage a more convincing and accurate measure of bargaining power, and use it in the first instance, changing to union density for robustness. ${ }^{20}$ An index of employment protection legislation, the benefit replacement ratio, the tax wedge between the production wage and the consumption wage, and a measure of the degree of coordination of bargaining in the economy fall into the second category. ${ }^{21}$

A description of the sources for these variables and their means and standard deviations are provided in Table A.3 in the data appendix.

\footnotetext{
${ }_{19}$ The scoreboard is available at http://europa.eu.int/comm/internal market/score/index en.htm

${ }^{20}$ The classic example is that of France, which has the lowest union density in our sample (12.5\%), but a very high level of bargaining coverage ( $90 \%)$.

${ }^{21}$ See Nickell at al (2005) for a discussion of these variables and their impact on unemployment outcomes.
} 


\section{Results}

We now turn to an empirical investigation of the predictions set out in Section 2. We start by considering the first stage, or reduced form, regression of average profitability on the indicators of product market reforms, before moving on to the main results examining the effects of changes in competition on employment and wages.

\subsection{The effect of product market reforms on average profitability}

The first stage regression of average profitability on indicators of product market reforms and all other controls takes the following form:

$$
\mu_{i t}=\gamma_{1} P M R_{i t}+\gamma_{2} L M R_{i t}+X_{i t}^{\prime} \gamma_{3}+f_{i}+t_{t}+\varepsilon_{i t}^{\mu}
$$

where $P M R_{i t}$ represents a vector of time and country varying indicators of product market regulation, $L M R_{i t}$ represents a vector of time and country varying indicators of labour market regulation (which are also included in the employment and wage regressions later on), and $X$ includes the output gap, changes in inflation, the real exchange rate, and the share of employment accounted for by the public sector, as discussed in Section 3.

All the product market variables are increasing with liberalisation, so a negative coefficient suggests that reforms which liberalise product markets are associated with lower average profitability. Column (1) in Table 1 shows the first stage using the SMP variable alone. We can see that it is highly statistically significant and negative, meaning that entering the SMP had a negative impact on average profitability, which we interpret as a positive impact on competition. The magnitude of the SMP effect is such that, if the SMP affected 50\% of industry, as it did in the case of the UK for example, then we estimate that economy-wide average profitability decreases by 3 percentage points as a result. ${ }^{22}$ In Column (2) we add in several other product market reforms, and the four variables together are significant at the $1 \%$ level. This is the first stage regression used to identify the linear competition effect in column (3) of Table 2.

${ }^{22}$ For example, using the estimate from column 1 in Table 1 , we have $0.00066 * 50=0.03$, which indicates a drop in profitability from e.g. 0.13 to 0.10 , or from $13 \%$ to $10 \% \ldots$ 
We estimate equations (9) and (10) both for the linear case (restricting $\alpha_{2}$ and $\beta_{2}$ to be zero) and including the interaction terms with bargaining power $\left(\alpha_{2}\right.$ and $\beta_{2}$ non-zero). Therefore we need reduced forms for both the linear variable and the interaction. In column (3) we interact the product market reforms with bargaining coverage. In the long run, when the number of firms in the economy is endogenous, Blanchard and Giavazzi (2003) show that the equilibrium level of rents in the economy depends on both entry costs and workers' bargaining power, which justifies including these interactions in the first stage. ${ }^{23}$ We show at the bottom of column (5) of Table 2 that the excluded instruments have strong explanatory power, in the sense that they are jointly significant at the 1\% level and have a partial R-squared of about 9\%. In column (4) we show the reduced form for the interaction term, which has similar properties.

Table 1: The Impact of Product Market Reforms on Competition

\begin{tabular}{|c|c|c|c|c|}
\hline \multirow[t]{2}{*}{ Dependent variable: } & \multicolumn{3}{|c|}{ Profitability $\left(\mu_{i t}\right)$} & \multirow{2}{*}{$\begin{array}{c}\text { Profitability }\left(\mu_{i t}\right) * \\
\text { Bargaining Coverage in } \\
1986 \\
(4)\end{array}$} \\
\hline & (1) & (2) & (3) & \\
\hline \multirow[t]{2}{*}{ Single Market Programme } & -0.00066 & -0.00048 & -0.00060 & -0.01364 \\
\hline & {$[0.00026]$} & {$[0.00031]$} & {$[0.00032]$} & {$[0.02778]$} \\
\hline \multirow[t]{2}{*}{ Average Tariff Rate } & & -0.02813 & -0.02064 & -10.50267 \\
\hline & & {$[0.01601]$} & {$[0.05146]$} & {$[4.10911]$} \\
\hline \multirow[t]{2}{*}{ Government Bureaucracy } & & -0.00387 & -0.09118 & -5.23088 \\
\hline & & {$[0.00822]$} & {$[0.06655]$} & [5.29911] \\
\hline \multirow[t]{2}{*}{ Non-Tariff Barriers } & & 0.02075 & 0.01997 & 1.28659 \\
\hline & & {$[0.01435]$} & {$[0.01516]$} & {$[1.31458]$} \\
\hline Average Tariff Rate $*$ & & & -0.00017 & 0.09813 \\
\hline Bargaining Coverage 1986 & & & {$[0.00058]$} & \\
\hline Government Bureaucracy * & & & 0.00103 & 0.05005 \\
\hline Bargaining Coverage 1986 & & & {$[0.00079]$} & {$[0.06331]$} \\
\hline Tax Wedge * & & & 0.00010 & 0.00935 \\
\hline Bargaining Coverage 1986 & & & & {$[0.00651]$} \\
\hline $\begin{array}{l}\text { Labour market controls: Tax wedge, } \\
\text { employment protection, benefits, } \\
\text { coordination }\end{array}$ & Yes & Yes & Yes & Yes \\
\hline $\begin{array}{l}\text { Other controls: output gap, change in } \\
\text { inflation, real exchange rate, public } \\
\text { sector employment rate }\end{array}$ & Yes & Yes & Yes & Yes \\
\hline
\end{tabular}

Notes: The regressions include 206 observations on 14 countries over the period 1986-2000. Robust standard errors are in parentheses. All specifications include country and year dummies.

${ }^{23}$ See equation (8) on page 889 of Blanchard and Giavazzi (2003). We also tried including the SMP interacted with bargaining coverage but found that the data rejected this specification in the sense that the Hansen test in the second stage rejected the over-identifying restrictions. 


\subsection{Main Results}

We now turn to the estimation of the determinants of unemployment, as expressed in equation (9). In Table 2 we start in column (1) by looking at the relationship between labour market regulations and the unemployment rate. The results are consistent with those in Nickell et al (2005), and several other studies, in that taxes and the benefit replacement rate have a significantly positive effect on unemployment and coordination has a negative effect, whereas employment protection legislation has no significant effect on its own. ${ }^{24}$ The output gap has a significant negative coefficient as expected, the change in the inflation rate is not significant, and the real exchange rate has a significant negative coefficient, indicating that a more appreciated exchange rate is associated with a lower equilibrium level of unemployment. The coefficient on the public sector employment rate is significantly higher than minus one, suggesting that unemployment decreases less than one-for-one with an increase in public sector employment. In the robustness section we show that the results are robust to dropping some of these controls.

In column (2) we include the linear effect of average profitability on unemployment. The significant positive coefficient suggests that increasing competition (a decrease in profitability) decreases the unemployment rate. Controlling for the endogeneity of competition by using our IV estimator in column (3) indicates that the OLS estimates are negatively biased, as the coefficient becomes more positive when we instrument. This is as expected: for example unobserved shocks that increase profitability are likely to decrease unemployment. Instrumenting will also help to reduce any attenuation bias that may be present due to classical measurement error in profitability. At the bottom of column (3) we present diagnostics showing the strength and validity of the excluded instruments. The p-value and partial R2 of the excluded instruments suggest that they have power, and the Hansen test suggests that we can not reject the overidentifying restrictions that the policy reform variables can be excluded from this regression.

\footnotetext{
${ }^{24}$ Nickell et al (2005) find that interactions between different labour market institutions can be important in explaining unemployment. We do not investigate this possibility as our main focus is on the impact of product market competition.
} 
Table 2: The Impact of Competition on the Unemployment Rate

\begin{tabular}{|c|c|c|c|c|c|c|c|}
\hline \multirow{2}{*}{$\begin{array}{l}\text { Dependent variable: } \\
\text { Unemployment Rate }\end{array}$} & (1) & (2) & (3) & (4) & (5) & (6) & (7) \\
\hline & OLS & OLS & IV & OLS & IV & OLS & IV \\
\hline \multicolumn{8}{|l|}{ Competition Variables } \\
\hline Profitability & & $\begin{array}{c}6.857 \\
{[2.402]}\end{array}$ & $\begin{array}{c}17.102 \\
{[8.612]}\end{array}$ & $\begin{array}{l}-17.858 \\
{[5.705]}\end{array}$ & $\begin{array}{c}-0.272 \\
{[12.975]}\end{array}$ & $\begin{array}{l}-13.361 \\
{[3.855]}\end{array}$ & $\begin{array}{c}1.700 \\
{[7.538]}\end{array}$ \\
\hline $\begin{array}{l}\text { Profitability * Bargaining } \\
\text { Coverage in } 1986\end{array}$ & & & & $\begin{array}{c}0.300 \\
{[0.062]}\end{array}$ & $\begin{array}{c}0.375 \\
{[0.134]}\end{array}$ & & \\
\hline $\begin{array}{l}\text { Profitability * Union Density } \\
\text { in } 1986\end{array}$ & & & & & & $\begin{array}{c}0.297 \\
{[0.049]}\end{array}$ & $\begin{array}{c}0.157 \\
{[0.078]}\end{array}$ \\
\hline \multicolumn{8}{|l|}{ Labour Market Controls } \\
\hline Tax Wedge & $\begin{array}{c}0.109 \\
{[0.047]}\end{array}$ & $\begin{array}{c}0.118 \\
{[0.047]}\end{array}$ & $\begin{array}{c}0.131 \\
{[0.048]}\end{array}$ & $\begin{array}{c}0.079 \\
{[0.047]}\end{array}$ & $\begin{array}{c}0.099 \\
{[0.060]}\end{array}$ & $\begin{array}{c}0.039 \\
{[0.044]}\end{array}$ & $\begin{array}{c}0.083 \\
{[0.046]}\end{array}$ \\
\hline \multicolumn{8}{|l|}{ Employment Protection } \\
\hline Legislation & $\begin{array}{l}-0.271 \\
{[0.289]}\end{array}$ & $\begin{array}{l}-0.225 \\
{[0.279]}\end{array}$ & $\begin{array}{l}-0.157 \\
{[0.268]}\end{array}$ & $\begin{array}{l}-0.035 \\
{[0.266]}\end{array}$ & $\begin{array}{c}0.172 \\
{[0.328]}\end{array}$ & $\begin{array}{c}0.193 \\
{[0.270]}\end{array}$ & $\begin{array}{c}0.033 \\
{[0.281]}\end{array}$ \\
\hline Benefits Replacement Ratio & $\begin{array}{c}10.72 \\
{[2.984]}\end{array}$ & $\begin{array}{l}9.591 \\
{[3.055]}\end{array}$ & $\begin{array}{c}7.905 \\
{[3.149]}\end{array}$ & $\begin{array}{c}6.943 \\
{[2.948]}\end{array}$ & $\begin{array}{c}2.360 \\
{[3.844]}\end{array}$ & $\begin{array}{c}8.810 \\
{[2.455]}\end{array}$ & $\begin{array}{c}8.268 \\
{[2.525]}\end{array}$ \\
\hline Coordination Index & $\begin{array}{l}-1.328 \\
{[0.364]}\end{array}$ & $\begin{array}{l}-1.446 \\
{[0.367]}\end{array}$ & $\begin{array}{l}-1.622 \\
{[0.384]}\end{array}$ & $\begin{array}{l}-1.172 \\
{[0.391]}\end{array}$ & $\begin{array}{l}-1.513 \\
{[0.485]}\end{array}$ & $\begin{array}{l}-0.885 \\
{[0.327]}\end{array}$ & $\begin{array}{l}-1.245 \\
{[0.363]}\end{array}$ \\
\hline \multicolumn{8}{|l|}{ Other Controls } \\
\hline Output Gap & $\begin{array}{l}-0.515 \\
{[0.044]}\end{array}$ & $\begin{array}{l}-0.563 \\
{[0.047]}\end{array}$ & $\begin{array}{l}-0.635 \\
{[0.075]}\end{array}$ & $\begin{array}{l}-0.566 \\
{[0.046]}\end{array}$ & $\begin{array}{l}-0.733 \\
{[0.074]}\end{array}$ & $\begin{array}{l}-0.545 \\
{[0.046]}\end{array}$ & $\begin{array}{l}-0.592 \\
{[0.058]}\end{array}$ \\
\hline Change in Inflation & $\begin{array}{l}-1.454 \\
{[5.830]}\end{array}$ & $\begin{array}{c}0.246 \\
{[5.740]}\end{array}$ & $\begin{array}{c}2.786 \\
{[6.325]}\end{array}$ & $\begin{array}{l}-0.231 \\
{[5.555]}\end{array}$ & $\begin{array}{c}5.549 \\
{[8.278]}\end{array}$ & $\begin{array}{l}-1.259 \\
{[4.999]}\end{array}$ & $\begin{array}{c}0.822 \\
{[5.007]}\end{array}$ \\
\hline Real Exchange Rate & $\begin{array}{l}-0.070 \\
{[0.012]}\end{array}$ & $\begin{array}{c}-0.057 \\
{[0.013]}\end{array}$ & $\begin{array}{c}-0.037 \\
{[0.022]}\end{array}$ & $\begin{array}{l}-0.062 \\
{[0.012]}\end{array}$ & $\begin{array}{c}-0.018 \\
{[0.023]}\end{array}$ & $\begin{array}{l}-0.063 \\
{[0.012]}\end{array}$ & $\begin{array}{c}-0.049 \\
{[0.016]}\end{array}$ \\
\hline Public Sector Employment Rate & $\begin{array}{c}-0.546 \\
{[0.122]}\end{array}$ & $\begin{array}{l}-0.537 \\
{[-.109]}\end{array}$ & $\begin{array}{c}-0.523 \\
{[0.093]}\end{array}$ & $\begin{array}{l}-0.396 \\
{[0.107]}\end{array}$ & $\begin{array}{c}-0.329 \\
{[0.119]}\end{array}$ & $\begin{array}{l}-0.491 \\
{[0.102]}\end{array}$ & $\begin{array}{l}-0.505 \\
{[0.091]}\end{array}$ \\
\hline Constant & $\begin{array}{c}4.783 \\
{[2.829]}\end{array}$ & $\begin{array}{c}-4.778 \\
{[4.248]}\end{array}$ & $\begin{array}{c}-19.061 \\
{[12.780]}\end{array}$ & $\begin{array}{l}35.951 \\
{[8.513]}\end{array}$ & $\begin{array}{l}-29.396 \\
{[12.346]}\end{array}$ & $\begin{array}{c}35.451 \\
{[7.079]}\end{array}$ & $\begin{array}{l}-8.651 \\
{[8.436]}\end{array}$ \\
\hline $\begin{array}{ll}1^{\text {st }} \text { Stage P-value: } & \text { linear } \\
\text { interaction }\end{array}$ & & & $\begin{array}{c}0.0053 \\
-\end{array}$ & & $\begin{array}{l}0.0016 \\
0.0003\end{array}$ & & $\begin{array}{l}0.0001 \\
0.0000\end{array}$ \\
\hline $\begin{aligned} 1^{\text {st }} \text { Stage Partial R2: linear } \\
\text { interaction }\end{aligned}$ & & & $\begin{array}{c}0.0622 \\
-\end{array}$ & & $\begin{array}{l}0.0878 \\
0.1075\end{array}$ & & $\begin{array}{l}0.1460 \\
0.2590\end{array}$ \\
\hline $\begin{array}{l}\text { P-value for Hansen test of over- } \\
\text { identifying restrictions }\end{array}$ & & & 0.20 & & 0.27 & & 0.08 \\
\hline
\end{tabular}

Notes: The regressions include 206 observations on 14 countries over the period 1986-2000. Robust standard errors are in parentheses. All specifications include country and year dummies.

In columns (4) and (5) we look at how the impact of increased competition varies with collective bargaining coverage, measured at the beginning of the sample period to mitigate potential problems of endogeneity. In columns (6) and (7) we consider the equivalent interaction with union density. The results provide evidence of interaction effects with both bargaining coverage and union density, and in both cases they are as theory predicts: an increase in competition 
decreases the unemployment rate more so in the presence of strong worker bargaining power. In the case of bargaining coverage the interaction effect becomes slightly larger once we instrument, whereas with union density the interaction becomes smaller, but the linear effect larger. We have no strong a priori reason to believe that the direction of the bias in the interaction term should be positive or negative. However, the mean effect in both cases increases, which is consistent with the hypothesis that any bias in profitability dampens the estimated effect of competition. At the bottom of columns (5) and (7) the p-values for the test of significance of the excluded instruments and the partial R2 suggest that the instruments have power. In column (5) we cannot reject the validity of the overidentifying exclusion restrictions, while in column (7) we can not reject at the 5\% level, but can at the $10 \%$ level.

What are the economic magnitudes of these effects? The magnitude of the results in column (3) suggest that a 3 percentage point drop in profitability predicted for the UK's entry into the SMP would, all else equal, result in a decrease in the unemployment rate of 0.51 of a percentage point $\left(17^{*}-0.03\right)$. To assess the magnitude of the interaction in column (5) we can compare the effect of a 3 percentage point drop in profitability on economies that have a bargaining coverage one standard deviation either side of the mean (which is 75\%). An economy with an initial coverage of $53 \%$, somewhere between that of Canada (39\%) and the UK (64\%), will experience a decrease in the unemployment rate of 0.59 percentage points $(-0.03 *(-0.27+0.38 * 53))$, whereas an economy with an initial coverage of $97 \%$, similar to that of Austria (99\%), will experience a decrease of 1.08 percentage points $(-0.03 *(-0.27+0.38 * 97))$, a difference of half a percentage point. The coefficient when we use union density is smaller and the comparable difference in the unemployment effect between a low density economy and a high density economy is 0.21 percentage points, again corresponding to one standard deviation either side of the cross-country mean. The smaller interaction effect with union density is consistent with our view that, perhaps, it does not measure bargaining power as well as coverage.

Table 3 presents the results for the wage regression as written in equation (10). Ideally we would like to use economy-wide average real wages as the dependent variable, however, for many of the countries in our sample real wages are only available for the manufacturing sector. Therefore, we start by showing results for real wages in manufacturing (in the left hand panel of the table) and then look at real total labour costs (in the right hand panel) which we have for the whole economy. We use the appropriate measure of profitability in each case. 
In column (1) when we include profitability in manufacturing in an OLS regression on real wages we find no impact. In column (2) we use an instrumental variables estimator to control for the potential endogeneity of profitability. At the bottom of the table we show that the instruments are both powerful and valid for profitability in the manufacturing sector. The significant negative coefficient on profitability suggests that competition has a positive effect on wages. The difference between the OLS and IV estimates suggests that the OLS coefficient is biased upwards, as would be expected if there was a positive correlation between profitability and wages due to unobserved shocks or other factors. As before, instrumenting will also help to reduce any attenuation bias that may be present due to classical measurement error in profitability.

Consider as before the impact of joining the SMP on a country such as the UK where $50 \%$ of industry was expected to be affected. The coefficient (standard error) on the SMP variable in the first stage for manufacturing is -0.0019 (0.0003), suggesting that the impact of the SMP was to reduce average profitability in UK manufacturing by about 9 percentage points $(0.0019 * 50)$. The coefficient on profitability in column (2) of Table 3 implies that the predicted impact of the SMP in UK manufacturing was an increase in the real wage of about 5.4\%.

In column (3) we include the interaction with bargaining coverage in an OLS regression, and in column (4) we use our IV estimator. Recall from Section 2 that, to the extent that bargaining deviates from right-to-manage, we expect the positive impact of competition on real wages to be smaller in countries where workers have high levels of bargaining power. The results in column (4) are consistent with this prediction, although the interaction is only significant at $10 \%$. Using the same 9 percentage point reduction in average profitability as in the example above, the size of the effect is such that a low bargaining coverage country (53\% as before) will experience an increase of about $4.5 \%$ in real wages $(-0.09 *(-79+0.55 * 53))$, whereas a high coverage country $(97 \%$ as before) will experience an increase of only $2.3 \%(-0.09 *(-79+0.55 * 97))$. Theory suggests that workers should be better off in all countries and our results are consistent with this: even with a coverage of $100 \%$ the interaction effect does not outweigh the linear effect. 
Table 3: The Impact of Competition on the Real Wage

\begin{tabular}{|c|c|c|c|c|c|c|c|c|}
\hline \multirow[t]{4}{*}{ Dependent variable: } & \multirow{2}{*}{\multicolumn{4}{|c|}{$\begin{array}{c}\text { Log of Real Wage Index } \\
\text { Manufacturing }\end{array}$}} & \multicolumn{4}{|c|}{ Log of Real Labour Costs Per Hour } \\
\hline & & & & & \multirow{3}{*}{$\begin{array}{c}\text { Manuf. } \\
(5) \\
\text { OLS }\end{array}$} & \multicolumn{3}{|c|}{ Total Economy } \\
\hline & (1) & (2) & (3) & (4) & & (6) & (7) & (8) \\
\hline & OLS & IV & OLS & IV & & OLS & OLS & IV \\
\hline \multicolumn{9}{|l|}{ Competition Variables } \\
\hline Profitability (manuf) & $\begin{array}{l}-1.056 \\
{[9.471]}\end{array}$ & $\begin{array}{l}-60.291 \\
{[21.670]}\end{array}$ & $\begin{array}{l}-69.685 \\
{[19.551]}\end{array}$ & $\begin{array}{l}-79.082 \\
{[23.550]}\end{array}$ & $\begin{array}{l}-76.626 \\
{[16.942]}\end{array}$ & & & \\
\hline Profitability (manuf.)* & & & 0.899 & 0.546 & 0.870 & & & \\
\hline $\begin{array}{l}\text { Bargaining Coverage in } \\
1986\end{array}$ & & & {$[0.220]$} & {$[0.306]$} & {$[0.192]$} & & & \\
\hline Profitability (priv. sec.) & & & & & & $\begin{array}{l}-145.706 \\
{[25.641]}\end{array}$ & $\begin{array}{l}-124.116 \\
{[28.126]}\end{array}$ & $\begin{array}{l}-176.422 \\
{[61.486]}\end{array}$ \\
\hline Profitability (priv. sec.)* & & & & & & 1.406 & 1.245 & 1.803 \\
\hline $\begin{array}{l}\text { Bargaining Coverage in } \\
1986\end{array}$ & & & & & & {$[0.272]$} & {$[0.313]$} & {$[0.569]$} \\
\hline \multicolumn{9}{|l|}{ Labour Market Controls } \\
\hline Tax Wedge & $\begin{array}{c}-0.165 \\
{[0.258]}\end{array}$ & $\begin{array}{c}-0.177 \\
{[0.259]}\end{array}$ & $\begin{array}{l}-0.271 \\
{[0.230]}\end{array}$ & $\begin{array}{l}-0.237 \\
{[0.229]}\end{array}$ & $\begin{array}{c}0.826 \\
{[0.150]}\end{array}$ & $\begin{array}{c}0.551 \\
{[0.158]}\end{array}$ & $\begin{array}{c}0.368 \\
{[0.161]}\end{array}$ & $\begin{array}{c}0.272 \\
{[0.167]}\end{array}$ \\
\hline $\begin{array}{l}\text { Employment Protection } \\
\text { Legislation }\end{array}$ & 0.435 & 1.39 & 1.931 & 1.93 & -1.303 & 0.171 & -0.945 & -0.436 \\
\hline & {$[1.521]$} & {$[1.448]$} & {$[1.505]$} & {$[1.435]$} & {$[1.116]$} & {$[1.108]$} & {$[1.040]$} & {$[1.055]$} \\
\hline Benefit Replacement Ratio & $\begin{array}{c}-1.295 \\
{[14.029]}\end{array}$ & $\begin{array}{c}-6.354 \\
{[15.084]}\end{array}$ & $\begin{array}{l}-17.892 \\
{[11.571]}\end{array}$ & $\begin{array}{c}-14.474 \\
{[13.986]}\end{array}$ & $\begin{array}{l}-0.200 \\
{[9.994]}\end{array}$ & $\begin{array}{l}11.453 \\
{[8.790]}\end{array}$ & $\begin{array}{l}14.893 \\
{[8.350]}\end{array}$ & $\begin{array}{l}10.175 \\
{[9.550]}\end{array}$ \\
\hline Coordination Index & $\begin{array}{c}2.488 \\
{[2.124]}\end{array}$ & $\begin{array}{c}-0.288 \\
{[2.395]}\end{array}$ & $\begin{array}{c}3.937 \\
{[2.022]}\end{array}$ & $\begin{array}{c}1.663 \\
{[2.294]}\end{array}$ & $\begin{array}{c}-0.221 \\
{[2.301]}\end{array}$ & $\begin{array}{c}-0.431 \\
{[2.069]}\end{array}$ & $\begin{array}{c}-2.035 \\
{[1.899]}\end{array}$ & $\begin{array}{l}-1.561 \\
{[1.824]}\end{array}$ \\
\hline \multicolumn{9}{|l|}{ Other Controls } \\
\hline Output Gap & $\begin{array}{c}0.241 \\
{[0.208]}\end{array}$ & $\begin{array}{c}0.666 \\
{[0.255]}\end{array}$ & $\begin{array}{c}0.27 \\
{[0.198]}\end{array}$ & $\begin{array}{c}0.52 \\
{[0.214]}\end{array}$ & $\begin{array}{c}0.233 \\
{[0.169]}\end{array}$ & $\begin{array}{c}0.290 \\
{[0.170]}\end{array}$ & $\begin{array}{c}0.261 \\
{[0.148]}\end{array}$ & $\begin{array}{c}0.307 \\
{[0.314]}\end{array}$ \\
\hline Change in Inflation & $\begin{array}{c}4.73 \\
{[30.814]}\end{array}$ & $\begin{array}{l}-19.143 \\
{[28.468]}\end{array}$ & $\begin{array}{c}3.027 \\
{[33.253]}\end{array}$ & $\begin{array}{l}-10.964 \\
{[27.658]}\end{array}$ & $\begin{array}{c}-1.903 \\
{[40.123]}\end{array}$ & $\begin{array}{c}9.715 \\
{[31.629]}\end{array}$ & $\begin{array}{c}9.295 \\
{[31.640]}\end{array}$ & $\begin{array}{c}7.714 \\
{[32.918]}\end{array}$ \\
\hline Real Exchange Rate & $\begin{array}{c}0.021 \\
{[0.074]}\end{array}$ & $\begin{array}{c}-0.22 \\
{[0.106]}\end{array}$ & $\begin{array}{c}0.004 \\
{[0.068]}\end{array}$ & $\begin{array}{l}-0.138 \\
{[0.085]}\end{array}$ & $\begin{array}{c}0.002 \\
{[0.054]}\end{array}$ & $\begin{array}{c}0.102 \\
{[0.046]}\end{array}$ & $\begin{array}{c}0.16 \\
{[0.052]}\end{array}$ & $\begin{array}{c}0.141 \\
{[0.087]}\end{array}$ \\
\hline Constant & $\begin{array}{c}4.694 \\
{[0.189]}\end{array}$ & $\begin{array}{c}5.730 \\
{[37.144]}\end{array}$ & $\begin{array}{c}5.336 \\
{[24.770]}\end{array}$ & $\begin{array}{c}5.470 \\
{[29.622]}\end{array}$ & $\begin{array}{c}3.799 \\
{[20.563]}\end{array}$ & $\begin{array}{c}4.302 \\
{[30.179]}\end{array}$ & $\begin{array}{c}4.164 \\
{[33.395]}\end{array}$ & $\begin{array}{c}2.174 \\
{[56.449]}\end{array}$ \\
\hline Observations & 176 & 176 & 176 & 176 & 176 & 176 & 206 & 206 \\
\hline $\begin{array}{l}1^{\text {st }} \text { Stage P-value: linear } \\
\text { interaction }\end{array}$ & & $\begin{array}{c}0.0000 \\
-\end{array}$ & & $\begin{array}{l}0.0000 \\
0.0000\end{array}$ & & & & $\begin{array}{l}0.0329 \\
0.0013\end{array}$ \\
\hline $1^{\text {st }}$ Stage Partial R2: linear & & 0.2229 & & 0.3380 & & & & $\begin{array}{l}0.2499 \\
04045\end{array}$ \\
\hline $\begin{array}{l}\text { P-value for Hansen test of } \\
\text { over-identifying restrictions }\end{array}$ & & 0.14 & & 0.14 & & & & 0.08 \\
\hline
\end{tabular}

Notes: The regressions include 176 observations on 13 countries over the period 1985-2000. Compared to the other Tables we lose Portugal, most of Norway and a few observations from Austria, Belgium and France. Robust standard errors appear in parentheses. Country and year dummies are included throughout. The set of excluded instruments are the same as for the unemployment regressions, except that non-tariff barriers is not used as its exclusion fails the Hansen test. 
To investigate this further, and in particular to see whether there is an interaction effect at the level of the total economy, we also use data on real labour costs per hour worked as a proxy for wages in the right hand panel of Table 3. In column (5) we run the equivalent OLS specification to column (3) on the same sample and see that the coefficients on the competition measures are broadly similar, suggesting that labour costs is a good proxy for wages (conditional on the other controls). The coefficients on the tax wedge and other labour market controls are quite different. This is because they are, in part, controlling for differences between labour costs and wages. In particular the coefficient on the tax wedge is now positive and significant, as would be expected given that payroll taxes are included in labour costs.

In column (6) we run the same regression but now using data for the whole economy for the same combination of country-year observations. The basic results are very similar to the manufacturing results, although the size of both coefficients on the competition measures is about twice as large. However, as we shall see below, after accounting for the different means of the variables and different effects of the product market reform variables on average profitability between the two samples, the overall predicted effects of product market reforms on real wages is similar.

In column (7) we run the same regression as in column (6) but now for the larger sample for which we have data on labour costs rather than wages (see data appendix for details). This makes little difference. In column (8) we use our IV estimator to control for possible endogeneity of profitability. As with wages in manufacturing we see that the direction of the OLS bias on the overall effect is positive. Consider the same 3 percentage point reduction in average profitability as a result of the SMP as in the total economy example for unemployment. The size of the effect in column (8) is such that a low bargaining coverage country ( $53 \%$ as before) will experience an increase of about $2.4 \%$ in real wages $(-0.03 *(-176+1.80 * 53))$, whereas a high coverage country $(97 \%$ as before) will experience an increase of only $0.1 \%(-0.03 *(-176+1.80 * 97))$.

\subsection{Economic significance}

Table 4 further quantifies the economic significance of our estimates by comparing the actual changes in unemployment and wages for each country between 1988 and 1998 (the years between which we have a balanced panel of countries) to the predicted changes from product market reforms based on our estimates. In each case we first examine the predicted impact of the 
SMP for participant countries, and then the predicted impact of changes in all the product market reform variables. In all cases we have controlled for common year effects and country-specific business cycles and macroeconomic shocks, so changes are relative to the cross-country average. For unemployment we have also controlled for the share of employment in the public sector. The predicted changes use estimates from column (4) of Tables 2 and 3 respectively.

Beginning with the impact on unemployment, the table shows that the predicted effects of product market reforms in reducing unemployment are substantial. For some of the countries the SMP variable accounts for a large part of the impact, but the other product market variables also explain a significant amount of variation. For example, our estimates suggest that the SMP was associated with a 1.1 percentage point reduction in the unemployment rate in Portugal, while all the product market reforms that we measure were together associated with a 2.6 percentage point reduction. This compares with an actual reduction in the unemployment rate relative to the crosscountry average trend of 1.1 percentage points. Thus factors other than product market reforms appear to have been responsible for an increase in the unemployment rate relative to the crosscountry average trend of 1.5 percentage points. Overall the predicted changes due to all the product market reforms are positively correlated with the actual changes across countries, with a correlation coefficient of 0.35 .

The predicted effects for real manufacturing wages are also substantial. The impact of the SMP makes up a larger amount of the total variation than in the case of total economy unemployment, which is perhaps unsurprising given that the main impact of the SMP was in manufacturing industries. Overall, the predicted changes due to all the product market reforms are again positively correlated with the actual changes across countries, but the correlation coefficient is lower than before at 0.20 . Thus, while the predicted impact of product market reforms on both unemployment and wages is highly significant in economic terms, in both cases there remains a significant amount of variation over time that is not explained by reforms to product markets. 
Table 4: Predicted effects of product market reforms, 1988 to 1998

\begin{tabular}{|c|c|c|c|c|c|c|}
\hline \multirow[b]{2}{*}{ Country } & \multicolumn{3}{|c|}{ Total Economy } & \multicolumn{3}{|c|}{ Manufacturing } \\
\hline & $\begin{array}{c}(1) \\
\Delta \text { Unemployment }\end{array}$ & $\begin{array}{l}(2) \\
\text { Explained by } \\
\text { SMP }\end{array}$ & $\begin{array}{l}(3) \\
\text { Explained by all } \\
\text { product market } \\
\text { reforms }\end{array}$ & $\begin{array}{c}(4) \\
\Delta \text { Manufacturing } \\
\text { Real Wage }\end{array}$ & $\begin{array}{l}(5) \\
\text { Explained by } \\
\text { SMP }\end{array}$ & $\begin{array}{l}(6) \\
\text { Explained by all } \\
\text { product market } \\
\text { reforms }\end{array}$ \\
\hline Australia & 0.2 & 0.0 & -0.2 & -2.6 & 0.0 & 2.8 \\
\hline Austria & 2.9 & 0.0 & -0.2 & -1.2 & 0.0 & 1.1 \\
\hline Belgium & -1.6 & -1.0 & -0.4 & -1.4 & 4.0 & 2.5 \\
\hline Canada & -3.5 & 0.0 & 0.2 & -1.1 & 0.0 & -3.5 \\
\hline Denmark & -0.4 & -0.8 & -2.2 & 5.8 & 5.0 & 7.2 \\
\hline Finland & 4.8 & 0.0 & 1.6 & 14.0 & 0.0 & -0.5 \\
\hline France & 1.3 & -1.0 & -1.3 & $0.9^{*}$ & 4.0 & 4.2 \\
\hline United Kingdom & -5.9 & -0.7 & -1.3 & 8.7 & 5.8 & 7.1 \\
\hline Italy & 0.2 & -1.0 & -1.1 & -6.5 & 4.5 & 5.1 \\
\hline The Netherlands & -1.2 & -0.8 & -2.9 & 14.0 & 4.2 & 7.4 \\
\hline Norway & 2.7 & 0.0 & -1.4 & - & - & - \\
\hline Portugal & -1.1 & -1.1 & -2.6 & - & - & - \\
\hline Sweden & 2.5 & 0.0 & -0.3 & -7.7 & 0.0 & 0.4 \\
\hline USA & -1.0 & 0.0 & -0.2 & -12.2 & 0.0 & 5.2 \\
\hline
\end{tabular}

Notes: All columns are calculated using de-trended values, controlling for the business cycle, the real exchange rate and changes in the inflation rate, and, in the case of unemployment, the public sector employment rate.

* This is the 1988 to 1997 difference, due to lack of wage data for France in 1998.

\subsection{Robustness}

We now turn to a number of potential robustness concerns. First, we investigate whether our results are robust to controlling for the level of bargaining coordination. We then consider two forms of measurement error - we use an alternative measure of the cost of capital that does not assume open capital markets, and we use employment, rather than unemployment, as the dependent variable. We also test that our results are robust to the set of control variables included. These are discussed in turn.

The first concern is whether our main results are robust to controlling for the level of bargaining coordination. As discussed in Section 2, to the extent that true economy-wide coordination does lead to more moderate wage demands, we should expect to see that the interaction between product market competition and measures of union density or bargaining coverage is less strong in coordinated countries. However, to the extent that the main effect of coordination is to 
increase workers' bargaining power we should expect to find that the impact of competition on employment is larger (and the impact on wages smaller) in more coordinated economies. ${ }^{25}$

To investigate this we split the countries in our sample into three groups according to the average value of their coordination index. The highly coordinated countries are Austria, Denmark, Finland, The Netherlands and Norway; the intermediates are Belgium, France, Italy, Portugal and Sweden; and the low coordination countries are Australia, Canada, the UK and the USA. ${ }^{26}$ In the first column of Table 5 we extend the specification in column (4) of Table 2 to include interactions between dummies for the high and intermediate coordination groups and the average level of profitability, as well as interactions between these and the level of bargaining coverage. If the interaction effect between increased competition and bargaining coverage is indeed less strong in highly coordinated countries we would expect to see a significant negative coefficient on the three-way interaction between average profitability, bargaining coverage, and the dummy for the highly coordinated group. While the estimated coefficient is indeed negative it is insignificant, and the same is true for all of the additional interactions.

In the second column we test the simpler alternative hypothesis - that the main effect of coordination is in fact to increase worker bargaining power. In other words, any incentives that coordinated worker-consumers have to moderate their wage demands are more than offset by an increase in their bargaining power due to the lower elasticity of demand for their (combined) product. To test this we drop both of the three-way interactions and include only the interactions between the dummies for the highly coordinated and intermediate groups and the average level of profitability. As well as a significant positive coefficient on our usual interaction between average profitability and bargaining coverage, we also find significant positive coefficients on both of these additional interactions. This provides some evidence in support of the hypothesis that the main effect of coordination is in fact to increase worker bargaining power. Thus the largest effect of increased competition on employment is in countries where bargaining coverage is high and coordination is also intermediate or high.

\footnotetext{
${ }^{25}$ For example, Flanagan (1999) argues that centralised bargaining in many OECD countries is "more form than substance" (p. 1167)

${ }^{26}$ The results are robust to changing the categorisation so that only Finland, The Netherlands and Norway are considered as highly coordinated.
} 
Table 5: Coordinated Bargaining

\begin{tabular}{|c|c|c|c|c|}
\hline \multirow[t]{3}{*}{ Dependent variable: } & \multicolumn{2}{|c|}{ Unemployment Rate } & \multicolumn{2}{|c|}{$\begin{array}{l}\text { Log of Real Labour Costs Per } \\
\text { Hour, Total Economy }\end{array}$} \\
\hline & (1) & (2) & (3) & (4) \\
\hline & OLS & OLS & OLS & OLS \\
\hline \multirow[t]{2}{*}{ Profitability } & -22.012 & -20.089 & -125.531 & -121.213 \\
\hline & [6.489] & [5.595] & [33.393] & [27.465] \\
\hline \multirow[t]{2}{*}{ Profitability * Bargaining Coverage in 1986} & 0.230 & 0.201 & 0.989 & 0.923 \\
\hline & [0.083] & [0.079] & {$[0.547]$} & {$[0.430]$} \\
\hline \multirow[t]{2}{*}{ Profitability * Intermediate Coordination Dummy } & 36.675 & 12.735 & -9.509 & 0.809 \\
\hline & {$[37.627]$} & {$[4.465]$} & [421.416] & {$[23.411]$} \\
\hline \multirow[t]{2}{*}{ Profitability * High Coordination Dummy } & 17.706 & 10.918 & 53.641 & 35.417 \\
\hline & {$[17.954]$} & [4.169] & {$[58.575]$} & {$[20.570]$} \\
\hline \multirow{2}{*}{$\begin{array}{l}\text { Profitability * Intermediate Coordination Dummy } \\
\text { * Bargaining Coverage in } 1986\end{array}$} & -0.289 & - & 0.104 & - \\
\hline & {$[0.442]$} & & [4.883] & \\
\hline \multirow{2}{*}{$\begin{array}{l}\text { Profitability * High Coordination Dummy } \\
\text { * Bargaining Coverage in } 1986\end{array}$} & -0.088 & - & -0.233 & - \\
\hline & {$[0.204]$} & & {$[0.782]$} & \\
\hline $\begin{array}{l}\text { Labour market controls: Tax wedge, employment } \\
\text { protection, benefits, coordination }\end{array}$ & Yes & Yes & Yes & Yes \\
\hline $\begin{array}{l}\text { Cyclical controls: output gap, change in inflation, } \\
\text { real exchange rate, public sector employment rate }\end{array}$ & Yes & Yes & Yes & Yes \\
\hline Observations & 206 & 206 & 206 & 206 \\
\hline
\end{tabular}

Robust standard errors appear in parentheses. All specifications include country and year dummies.

The highly coordinated countries are Austria, Denmark, Finland, The Netherlands and Norway; the intermediates are Belgium, France, Italy, Portugal and Sweden; and the low coordination countries are Australia, Canada, the UK and the USA. The results are robust to changing the categorisation so that only Finland, The Netherlands and Norway are considered as highly coordinated.

In columns (3) and (4) we repeat the same test for the log of real labour costs per hour in the total economy and the results are very similar. ${ }^{27}$ As before our previous results are robust and the three-way interactions between profitability, the coordination dummies and bargaining coverage are insignificant in column (3). In column (4) the interaction between profitability and the high coordination dummy is positive and significant, but only at the $10 \%$ level. These results suggest that our main result for labour costs is fairly robust across different measured levels of coordination, and that as above the main effect of coordination is if anything to increase workers' bargaining power.

\footnotetext{
${ }^{27}$ We do not use the manufacturing real wage index because the country coverage is less good (we lose Portugal and most of Norway), as described in the discussion of the main results. However, the results using the manufacturing real wage index are similar.
} 
A second concern is whether our results are sensitive to our measure of the cost of capital. In our main results we use the US long term interest rate to proxy variation over time in the cost of capital for all countries. This assumes that capital markets are fully open throughout the sample period. If capital markets were liberalized by some countries during the sample period in a way that was correlated with reforms to product markets this could potentially affect our results. To check the robustness of our results we re-ran all results assuming that capital markets are fully closed, and hence domestic interest rates are a better proxy for changes in the cost of capital. Our main results are robust to this change. ${ }^{28}$

We also check that our main results are robust to the set of control variables included. For example, if we drop the change in the inflation rate, the real exchange rate and the public sector employment rate from the specification in column (5) of Table 2 the main results are not significantly affected. For example, the coefficients (standard errors) on profitability and the interaction between profitability and bargaining coverage are $5.826(10.980)$ and $0.345(0.137)$ respectively.

Another potential measurement concern is with our use of the unemployment rate as the dependent variable. To investigate this we instead use the log of employment as the dependent variable, and include the size of the labour force as a control, as well as the log of public sector employment. Columns (1) and (2) in Table 6 show the OLS and IV estimates from this regression. The key difference between this and the unemployment regressions is that we no longer restrict the coefficient on the labour force to equal one. The key coefficients on profitability, and the interaction between profitability and bargaining coverage, are robust to this change of specification. In column (3) we drop the log of public sector employment and the main results are again unchanged.

\footnotetext{
${ }^{28}$ For example, for the instrumented unemployment regression (Table 2 column 3 ) the coefficient (standard error) on profitability, for the 185 observations for which the domestic interest rate is available, is 12.792 (4.777). In Table 2 column (5) the coefficients (standard errors) on profitability and the profitability*bargaining coverage terms are $-1.093(9.100)$ and $0.168(0.103)$ respectively. For the instrumented wage regression, using real labour costs per hour for the total economy (Table 3 column 8 ) the equivalent coefficients (standard errors) are -115.751 (28.206) and $1.556(0.310)$.
} 


\section{Table 6: Employment rather than unemployment rate}

\begin{tabular}{lccc}
\hline \hline Dependent variable: Log of employment, & $(1)$ & $(2)$ & $(3)$ \\
Total Economy & OLS & IV & IV \\
\hline Profitability & 0.14073 & -0.04246 & -0.03619 \\
& {$[0.05965]$} & {$[0.15008]$} & {$[0.15509]$} \\
Profitability * Bargaining Coverage in 1986 & -0.00237 & -0.00366 & -0.00415 \\
& {$[0.00067]$} & {$[0.00147]$} & {$[0.00150]$} \\
Log of labour force & 0.91962 & 0.87468 & 1.0195 \\
& {$[0.04578]$} & {$[0.06329]$} & {$[0.05064]$} \\
Log of public sector employment & 0.185 & 0.16075 & - \\
& {$[0.03579]$} & {$[0.04276]$} & \\
& & & Yes \\
Labour market controls: Tax wedge, & Yes & & \\
employment protection, benefits, coordination & & Yes & Yes \\
Cyclical controls: output gap, change in & Yes & & 206 \\
inflation, real exchange rate & & 206 & 0.23 \\
Observations & 206 & 0.31 & \\
P-value for Hansen test of & - & & \\
overidentifying restrictions & & & \\
\hline \hline
\end{tabular}

Robust standard errors appear in parentheses. Country and year dummies are included throughout.

The magnitude of the estimated effects in Table 6 are very similar to those using the unemployment rate. For example, consider again the impact of joining the SMP, which is associated with on average a 3 percentage point reduction in profitability, for a country with high bargaining coverage ( $97 \%$ as before). Using the estimates from column (2) of Table 6 , this is associated with a $0.95 \%$ increase in employment $(0.03 *(-0.042+(-0.0037 * 97))$, which is comparable with a predicted reduction in the unemployment rate of 1.08 percentage points calculated from column (5) of Table 2. The equivalent changes for a low bargaining coverage country ( $53 \%$ as before) are a $0.46 \%$ increase in employment predicted by column (2) of Table 6 $(0.03 *(-0.042+(-0.0037 * 53))$ and a 0.59 percentage point reduction in the unemployment rate predicted by column (5) of Table 2 . 


\section{Conclusion}

High rates of unemployment remain a key policy concern across many European countries. Attention has focused on labour market institutions as the main determinant of unemployment, but recent work suggests that they can not fully explain the variation across countries and over time. In this paper we have used time varying information on product market reforms to test theoretical predictions that higher levels of competition increase employment and real wages. We have also examined whether the increase is larger for employment and smaller for real wages when workers' bargaining power is higher.

Empirically we have shown that the significant product market de-regulation experienced in the 1990s by some OECD countries was associated with an increase in competition as measured by average firm profitability. Such exogenous increases in competition are further associated with increases in aggregate employment and the real wage. We estimate that in countries with higher levels of collective bargaining coverage and/or union density the increase in employment is more pronounced, and the increase in real wages less so. Although some of the key reforms that we have used specifically targeted manufacturing, we find that even manufacturing workers with very high bargaining coverage were, in real wage terms, better off as a result of the product market reforms.

Our results have interesting implications for policy. First, widespread product market reforms will benefit workers and the economy as a whole through increased employment and higher real wages. Second, the presence of strong unions is not a reason to shy away from product market reform - if anything there is more incentive to reform as the employment benefits may be larger. However, it is also under these circumstances that reform may be most resisted as existing workers have less to gain. 


\section{Data Appendix}

Our data consist of an unbalanced panel on 14 countries over the period 1986-2000. Table A.1 shows the structure of the panel. Spain and Greece are excluded from the analysis due to a lack of data availability, and Germany is excluded due to re-unification, which is likely to have swamped any effects from product market reform. The second panel of Table A.1 shows the mean and standard deviation of our measure of profitability. It is important to note that the inclusion of country dummies in all specifications controls for average differences across countries in the level of measured profitability due to differences in measurement or other differences that are constant over time. Thus the main results are identified from differential within-country changes over time.

Table A.1: Sample composition and average profitability by country

\begin{tabular}{lcc|cc}
\hline \hline Country & $\begin{array}{c}\text { Total economy } \\
\text { unemployment, labour } \\
\text { costs }\end{array}$ & $\begin{array}{c}\text { Manufacturing } \\
\text { wages }\end{array}$ & $\begin{array}{c}\text { Mean of average } \\
\text { profitability }\end{array}$ & Standard Deviation \\
\hline Australia & $1986-2000$ & $1986-2000$ & 1.2944 & 0.0596 \\
Austria & $1986-2000$ & $1986-1999$ & 1.2716 & 0.0505 \\
Belgium & $1986-2000$ & $1986-1998$ & 1.2995 & 0.0349 \\
Canada & $1986-2000$ & $1986-2000$ & 1.3972 & 0.0534 \\
Denmark & $1986-2000$ & $1986-2000$ & 1.4980 & 0.0456 \\
Finland & $1986-2000$ & $1986-2000$ & 1.2120 & 0.1011 \\
France & $1986-2000$ & $1986-1997$ & 1.2828 & 0.0259 \\
UK & $1986-2000$ & $1986-2000$ & 1.3679 & 0.0527 \\
Italy & $1986-2000$ & $1986-2000$ & 1.4889 & 0.0832 \\
The Netherlands & $1986-2000$ & $1986-1999$ & 1.2419 & 0.0560 \\
Norway & $1986-1999$ & $1997-1999$ & 1.2297 & 0.1283 \\
Portugal & $1988-1999$ & - & 1.2222 & 0.0275 \\
Sweden & $1986-2000$ & $1986-2000$ & 1.2029 & 0.0664 \\
USA & $1986-2000$ & $1986-2000$ & 1.3698 & 0.0376 \\
Total & 206 & 176 & 1.3127 & 0.1123 \\
\hline \hline
\end{tabular}




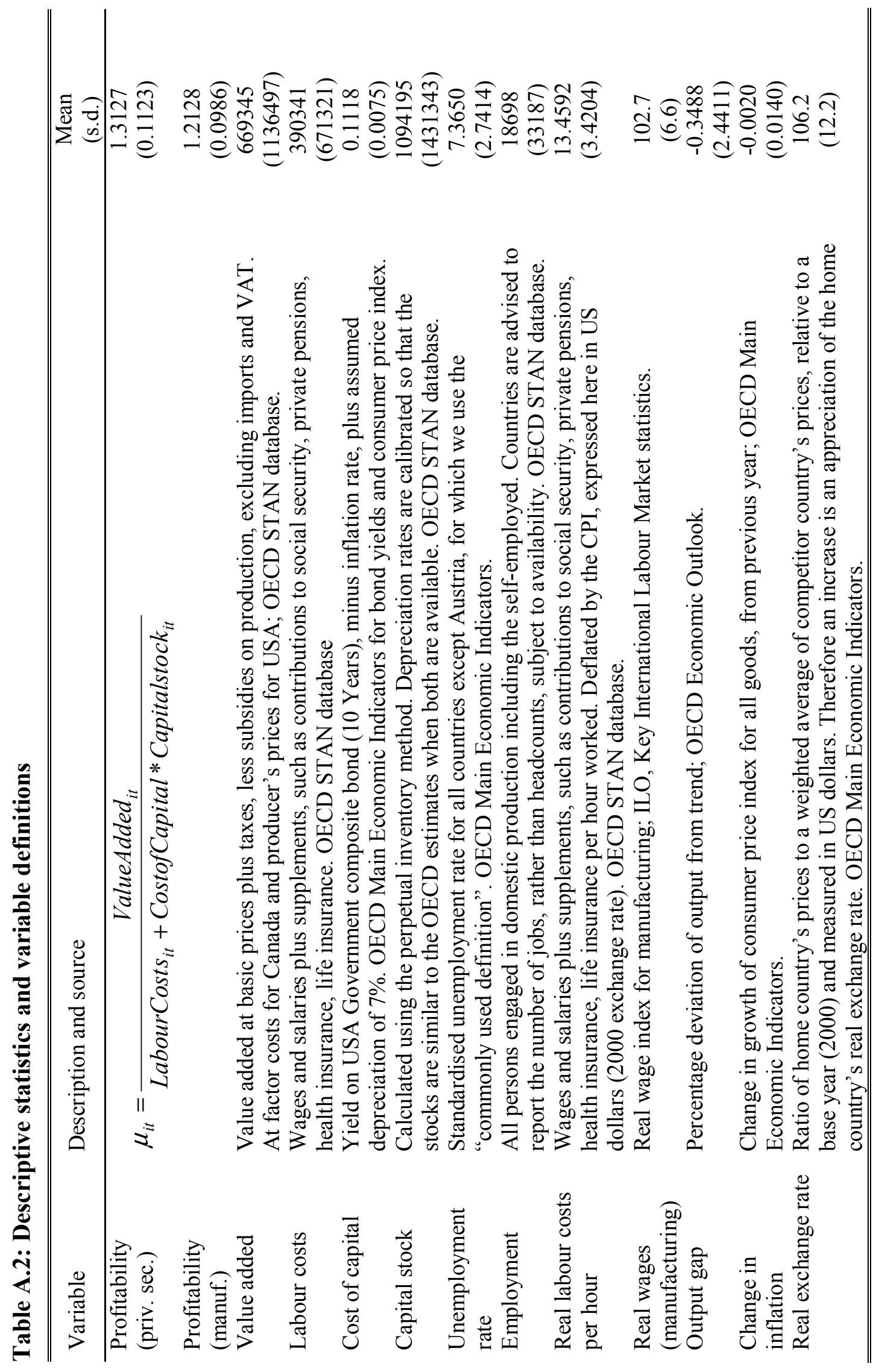

m 


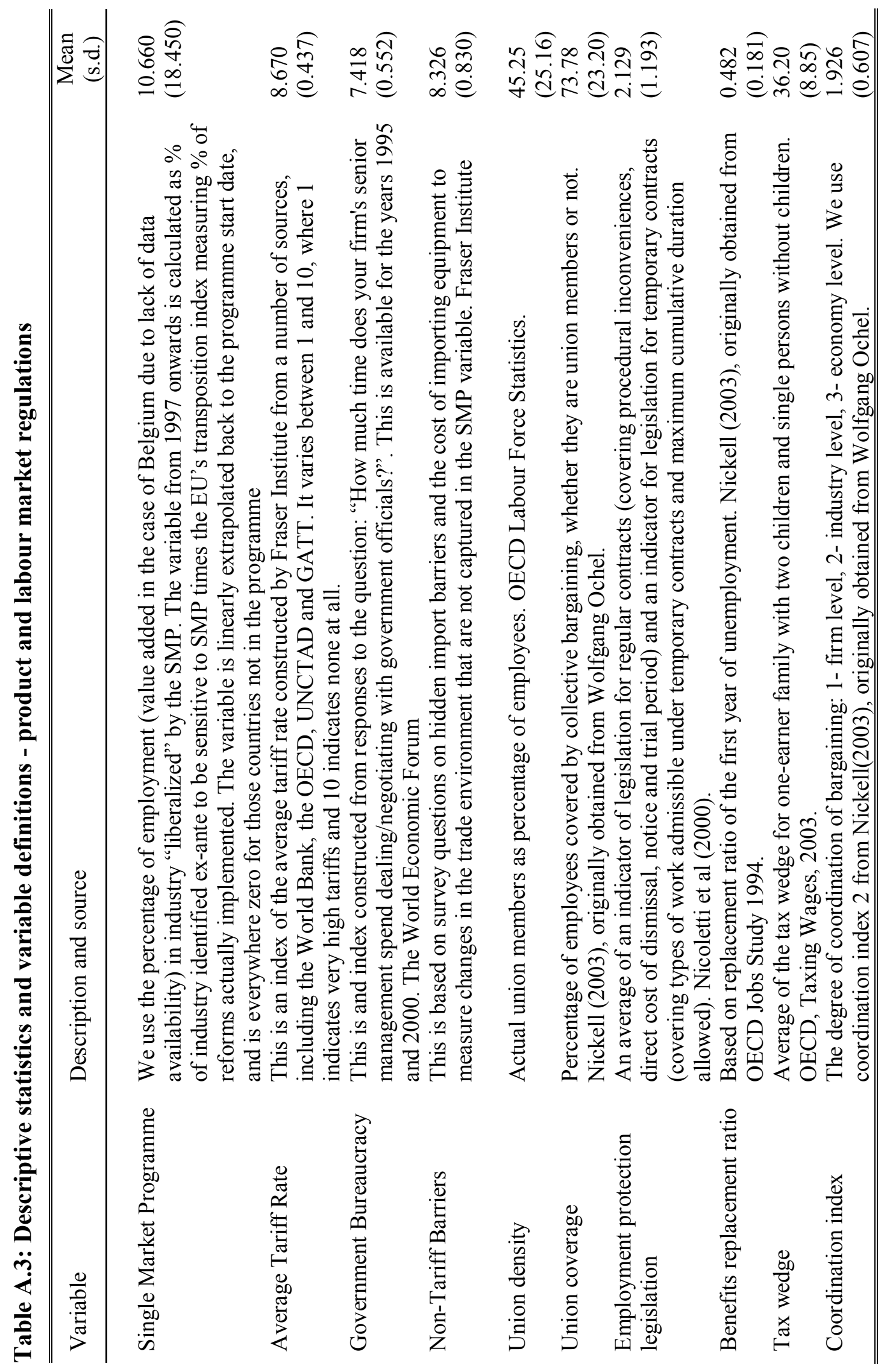




\section{References}

Anderson, Haldrup, Sorensen (2000) "Labour market implications of EU product market integration", Economic Policy, 30, pp. 107-133

Bassanini and Ernst (2002), "Labour market institutions, product market regulation, and innovation: cross-country evidence", OECD Economics Department Working Paper, No. 316

Belot, M. and J. van Ours (2001) "Unemployment and labour market institutions: an empirical analysis", Journal of Japanese and International Economics, 15, pp. 1-16

Bertrand, Marianne and Kramarz, Francis (2002) "Does Entry Regulation Hinder Job Creation? Evidence from the French Retail Industry" Quarterly Journal of Economics, November 2002, 117(4), pp. 1369-1413.

Blanchard, O. (2005) "European Unemployment: The Evolution of Facts and Ideas", MIT working paper 05-24

Blanchard, O. and Kiyotaki (1987) "Monopolistic Competition and the Effects of Aggregate Demand" The American Economic Review, 77, pp. 647-666

Blanchard, O. and Giavazzi (2003) "Macroeconomic effects of regulation and deregulation in goods and labor markets", The Quarterly Journal of Economics, August 2003, 879-907

Blanchard, O. and Wolfers (2000) "The Role of Shocks and Institutions in the Rise of European Unemployment: The Aggregate Evidence", The Economic Journal, 113, C1-C33

Boone, J. (2000): "Measuring Product Market Competition", CEPR Working Paper 2636

Bottasso, A. and Sembenelli, A. (1998) "Market power, productivity and the EU single market program: an ex-post assessment on Italian firm level data", Fondazione Eni Enrico Mattei Nota di Lavoro 17.98

Buigues, P, F. Ilkowitz and J. F. Lebrun (1991) "The impact of the internal market by industrial sector: the challenge for member states", European Economy, Special Issue

Calmfors and Driffill (1988) "Centralisation of Wage Bargaining and Macroeconomic Performance: A Survey", The Economics of Unemployment Vol III, (ed) PN Junankar

Card D. and R. Freeman (2002) "What have two decades of British economic reform delivered?" forthcoming in Blundell, Card and Freeman (eds) Seeking a Premier League Economy, Chicago: University of Chicago Press

Carlin, W. and D. Soskice (2005) "Macroeconomics: Imperfections, Institutions and Policies", forthcoming

Commendatore and Kubin (2005) "Dynamic effects of regulation and deregulation in goods and labour markets", Vienna University of Economics and Business Administration Working Paper, No. 49

Dasgupta and Stiglitz (1990) "Industrial Structure and the Nature of Innovative Activity" The Economic Journal Vol 90, Issue 358, 266-293

Dixit and Stiglitz (1977) "Monopolistic Competition and Optimum Product Diversity" The American Economic Review

Ebell and Haefke (2004) "The Missing Link: Product Market Regulation, Collective Bargaining and the European Unemployment Puzzle”, 2004 Meeting Papers 759, Society for Economic Dynamics

Elmeskov, J., J. Martin and S. Scarpetta (1998), "Key lessons for labour market reforms: evidence from OECD countries' experiences", Swedish Economic Policy Review, 5, pp. 205-252 
EU (2003) "An agenda for a growing Europe: making the EU economic system deliver" Report of an Independent High-Level Study group established on the initiative of the President of the European Commission, July 2003.

Fraser Institute (2002) Economic Freedom of the World: 2002 Annual Report

Flanagan R. J. (1999) "Macroeconomic Performance and Collective Bargaining: An International Perspective", Journal of Economic Literature

Garibaldi and Mauro (2002) "Anatomy of employment growth", Economic Policy

Griffith R. and R. Harrison (2004), "The link between product market reform and macroeconomic performance", European Economy Economic Papers, No. 209

Jackman R., R. Layard, S. Nickell, (1991), Unemployment, Oxford University Press

Jaquemin and Sapir (1991) "Competition and imports in European markets" in Winters, L. and A. Venables (eds.) European Integration: Trade and Industry, Cambridge University Press, Cambridge

Klette, T (1999) "Market Power, Scale Economies and Productivity: Estimates from a Panel of Establishment Data" The Journal of Industrial Economics December 1999, 451-476

Kugler, A. and G. Pica (2003) "Effects of employment protection and product market regulations on the Italian labour market", Institute for the Study of Labor, Discussion Paper 948

Layard and Nickell (1990) "Is unemployment lower if unions bargain over employment?" Quarterly Journal of Economics, Vol. 105, 773-787

Martins, J, Scarpetta, S and Pilat, D (1996) "Mark-up ratios in manufacturing industries: estimates for 14 OECD countries", OECD, Working Paper No. 162

Mayes, D. and P. Hart (1994) "The Single Market Programme as a Stimulus to change: comparisons between Britain and Germany", Cambridge University Press: Cambridge

OECD (1994) The OECD Jobs Study, http://www.oecd.org/dataoecd/42/51/1941679.pdf

Nickell, S. (1999) "Product Markets and Labour Markets" Labour Economics 6, no.1, 1-20

Nickell, S and R Layard (1999), 'Labor market institutions and economic performance', pages 3029-3084 in O. Ashenfelter and D. Card (eds) Handbook of Labor Economics Volume 3B (Amsterdam, North Holland).

Nickell, Nunziata, Ochel (2005) "Unemployment in the OECD since the 1960s. What do we know?", The Economic Journal, 115, 1-27

Nicoletti, G. and S. Scarpetta (2005) "Product market reforms and employment in OECD countries", OECD Economics Department Working Paper No. 472

Nicoletti, Scarpetta and Boylaud (2000) "Summary indicators of product market regulation with an extension to employment protection legislation.", OECD Economic Department Working Paper, No. 226

Pissarides, C. (2001), "Company start-up costs and employment", CEP Discussion Paper, No. 520, London School of Economics

Roeger, W. (1995) "Can Imperfect Competition Explain the Difference Between Primal and Dual Productivity Measures? Estimates for US Manufacturing” Journal of Political Economy 103, 316-330

Spector (2004) "Competition and the capital-labour conflict" European Economic Review 48, $25-38$ 